\title{
Association Between the 25-Hydroxyvitamin D Status and Physical Performance in Healthy Recreational Athletes
}

\author{
Cornelia Zeitler ${ }^{1}$, Robert Fritz ${ }^{2}$, Gerhard Smekal ${ }^{3}$ and Cem Ekmekcioglu ${ }^{1, *}$ \\ 1 Department of Environmental Health, Center for Public Health, Medical University of Vienna, \\ Kinderspitalgasse 15, 1090 Vienna, Austria; c.zeitler@hotmail.com \\ 2 Sportordination, Alser Straße 27/1/6, 1080 Vienna, Austria; fritz@sportordination.com \\ 3 Institute of Sport Sciences, University of Vienna, Auf der Schmelz 6a, 1150 Vienna, Austria; \\ gerhard.smekal@univie.ac.at \\ * Correspondence: cem.ekmekcioglu@meduniwien.ac.at; Tel.: +43-1-40160-34927
}

Received: 23 October 2018; Accepted: 29 November 2018; Published: 3 December 2018

check for updates

\begin{abstract}
Molecular and clinical studies have linked vitamin D (vitD) deficiency to several aspects of muscle performance. For this retrospective cross-sectional study data from 297 male (M) and 284 female $(\mathrm{F})$ healthy recreational athletes were used to evaluate the prevalence of vitD deficiency in athletes living in Austria and to determine whether serum 25-hydroxyvitamin D $(25(\mathrm{OH}) \mathrm{D})$ correlates with maximal $\left(\mathrm{P}_{\max }\right)$ and submaximal physical performance $\left(\mathrm{P}_{\text {submax }}\right)$ measured on a treadmill ergometer. The data were controlled for age, season, weekly training hours (WTH), body mass index (BMI) and smoking status. $96 \mathrm{M}$ and $75 \mathrm{~F}$ had 25(OH)D levels $\leq 20 \mathrm{ng} / \mathrm{mL}$. 25(OH)D levels showed seasonal variations, but no seasonal differences in $\mathrm{P}_{\max }$ and $\mathrm{P}_{\text {submax }}$ were detected. $\mathrm{M}$ with $25(\mathrm{OH}) \mathrm{D}$ levels $\leq 20 \mathrm{ng} / \mathrm{mL}$ had significantly lower $\mathrm{P}_{\text {submax }}(p=0.045)$ than those with normal levels. In $\mathrm{F}$ no significant differences in $\mathrm{P}_{\max }$ or $\mathrm{P}_{\text {submax }}$ were detected. Stepwise multiple regression analysis including all covariates revealed significant correlations between $25(\mathrm{OH}) \mathrm{D}$ levels and $\mathrm{P}_{\max }(\beta=0.138$, $p=0.003)$ and $\mathrm{P}_{\text {submax }}(\beta=0.152, p=0.002)$ in $\mathrm{M}$. Interestingly, for $\mathrm{F}$ significant correlations between 25(OH)D and both $\mathrm{P}_{\max }$ and $\mathrm{P}_{\text {submax }}$ disappeared after adding WTH to the model. In conclusion, our data suggest that $25(\mathrm{OH}) \mathrm{D}$ status is associated with physical performance especially in $\mathrm{M}$, while in $\mathrm{F}$, WTH and BMI seem to affect the correlation.
\end{abstract}

Keywords: vitamin D; maximal performance; submaximal performance; 25-hydroxyvitamin D $(25(\mathrm{OH}) \mathrm{D})$; physical activity; treadmill ergometer; athlete

\section{Introduction}

The discovery of vitamin D and its role in musculoskeletal pathways at the end of the 20th century has led to a significant decline in cases of rickets in children, with the awareness about vitamin D deficiency and its consequences getting a second boost at the moment [1].

Vitamin D is known for its critical role in musculoskeletal health through maintaining a homeostasis of calcium and phosphate by enhancement of their absorption in the small intestine [2] thus preventing bone fractures and falls, especially in older populations [3,4]. Moreover it has been proposed to play an important part in reducing the risk of multiple types of cancer $[5,6]$ as well as several autoimmune diseases $[7,8]$ and osteoarthritis [9]. A recent meta-analysis of observational studies by Ekmekcioglu et al. [6] showed that higher 25(OH)D levels are associated with lower risks for type 2 diabetes mellitus and colorectal cancer. Additionally vitamin D deficiency was shown to be associated with higher blood pressure [10], obesity [11] and higher blood lipid levels [12]. 
Out of the many forms in which vitamin D presents itself, vitamin $\mathrm{D}_{2}$ (ergocalciferol) and vitamin $\mathrm{D}_{3}$ (cholecalciferol) are the physiologically most important ones. While vitamin $\mathrm{D}_{3}$ can be found in fatty fish, egg yolks, liver and dairy products, mushrooms are a source for vitamin $\mathrm{D}_{2}$ [13]. The main source for vitamin D however, is the synthesis by the skin in reaction with UVB light. The metabolic steps in the liver and kidney leading to formation of the main circulating metabolite 25-hydroxyvitamin $\mathrm{D}(25(\mathrm{OH}) \mathrm{D})$ and the active metabolite 1,25-dihydroxyvitamin $\mathrm{D}\left(1,25(\mathrm{OH})_{2} \mathrm{D}\right)$ are regulated through multiple feedback mechanisms and are still under investigation [14].

According to recent findings the enzymatic systems needed to perform the activating hydroxylation step as well as the nuclear hormone receptor, vitamin D receptor (VDR), were detected in several cells all over the body, including muscle tissue [15]. Subsequently it is assumed that $1,25(\mathrm{OH})_{2} \mathrm{D}$ also influences skeletal muscle via molecular pathways [16].This hypothesis was tested in numerous observational and interventional studies. Most of the studies have been conducted in elderly populations, linking vitamin D deficiency to several aspects of muscle strength and performance such as handgrip, lower limb strength, balance, timed up and go test and gait speed [17-19]. However, also divergent results have been reported, showing no improvements in strength parameters following vitamin D supplementation in elderly populations [20,21].

Especially in the last two decades there have been increased efforts to determine the role of vitamin D in physical performance in younger populations and athletes. Vitamin D levels have been associated with various aspects of muscle strength and recovery in these populations as well, including for example hand-grip strength, gastro-soleus strength and walking distance in a group of young vitamin D deficient Asian Indians [22], hand-grip strength in a group of severely vitamin D deficient Somali women [23], isometric strength and relative grip strength in young hockey players [24], vertical jump and reduced injury risk after winter vitamin D supplementation in elite ballet dancers [25], $10 \mathrm{~m}$ sprint times and vertical jump height following supplementation in a sample of vitamin D deficient young athletes [26] as well as improved phosphocreatine recovery half-time of the soleus muscle in severely deficient individuals [27] and enhanced recovery following intense exercise in active male adults [28]. Again, several studies have yielded contradictory results showing no association between vitamin D levels and muscle strength parameters [29-32].

In accordance with the rising interest on vitamin $\mathrm{D}$, study groups all over the world have conducted research to determine the prevalence of vitamin D deficiency, with alarming results. According to Hilger et al. [33] 88.1\% of examined samples worldwide showed mean 25(OH)D levels beneath $75 \mathrm{nmol} / \mathrm{L}$ ( $30 \mathrm{ng} / \mathrm{mL}$; conversion factor: $1 \mathrm{ng} / \mathrm{mL}=2.496 \mathrm{nmol} / \mathrm{L}$ ), $37.3 \%$ with mean levels $<50 \mathrm{nmol} / \mathrm{L}(20 \mathrm{ng} / \mathrm{mL})$ and $6.7 \%$ with mean levels $<25 \mathrm{nmol} / \mathrm{L}(10 \mathrm{ng} / \mathrm{mL})$. Similar prevalence rates have been found for athletes [34]. However, a huge variability in all the collected data partly limits the significance of possible estimates on vitamin D levels.

Considering that there has not been a universal consensus on optimal vitamin levels yet, the comparison of studies investigating the results of insufficient vitamin D status on different health outcomes is particularly challenging. While the US Institute of Medicine Committee (IOM) proposes that $20 \mathrm{ng} / \mathrm{mL}$ ( $50 \mathrm{nmol} / \mathrm{L}$ ) as a cut-off level meets the needs of almost all of the general population [35], the US Endocrinology Society regards any 25(OH)D levels under $30 \mathrm{ng} / \mathrm{mL}(75 \mathrm{nmol} / \mathrm{L})$, and above $20 \mathrm{ng} / \mathrm{mL}$ (50 nmol/L) as insufficient [36].

The aim of this trial was to evaluate the prevalence of vitamin D deficiency in a large sample representing healthy recreational athletes in Austria and to determine whether vitamin D status correlates with both, maximal and submaximal physical performance on a treadmill ergometer.

\section{Materials and Methods}

The study was approved by the ethics committee of the Medical University of Vienna (EK-Number 1929/2016). The data used for this study were generated in "Sportordination", a multidisciplinary medical centre for sports medicine and sports sciences, located in 1080 Vienna, Austria. On their first visit all athletes had to fill out a questionnaire on their medical history, weekly training hours and 
personal best results at races. Following the medical check-up height, body weight and body fat were measured. Afterwards athletes performed an incremental performance test on a treadmill ergometer to subjective exhaustion supervised by a sports scientist. To ensure valid test results, all athletes were asked to refrain from doing any sports, drink enough fluid and have a full carbohydrate-based supper on the day prior to the performance test and to make sure that their last food intake was two hours before the test. According to the gathered information on training habits and race performance, the fitting protocol for the performance test was chosen. For athletes with half marathon minimum times under $2 \mathrm{~h}$ or $10 \mathrm{~km}$ minimum times under $60 \mathrm{~min}$ the following protocol was used: Initial running speed started at $6 \mathrm{~km} / \mathrm{h}$ with increments of $2 \mathrm{~km} / \mathrm{h}$ every $3 \mathrm{~min}$. This protocol has been proven sufficient for incremental performance tests of amateur athletes $[37,38]$.

At the beginning of the test blood lactate and glucose concentration were determined from capillary blood drawn from the earlobe at rest using "SUPER GL ambulance" (Dr. Müller Gerätebau $\mathrm{GmbH}$, Freital, Germany), a glucose and lactate measurement unit working with a compact sensor. During the test, the treadmill was stopped after each exercise level to determine lactate and glucose concentrations. Heart rate was measured continuously using telemetered electrocardiogram (ECG) recordings and blood pressure was checked regularly. $\mathrm{P}_{\max }$ was defined as highest possible speed $(\mathrm{km} / \mathrm{h})$ until subjective exhaustion. While maximal performance represents the overall fitness, submaximal performance is far more important to athletes as it determines their training status. During an incremental performance test lactate levels form a characteristic curve $[39,40]$ with a slight increase at the beginning due to accumulating lactate as long as heart rate and capillary dilatation have not adapted, and then stabilization just above baseline when oxidative phosphorylation is responsible for the mean part of energy production. There is a rise in lactate levels as the intensity increases and anaerobic glycolysis begins to take part in ATP production. Within this transition between aerobic and anaerobic energy production oxidative energy supply is no longer sufficient to keep up with the rising need for ATP. The capacity of mitochondria is pushed to its limits resulting in exponential rise in lactate levels as pyruvate production exceeds lactate clearance marking the individual anaerobic threshold (IAT). By measuring glucose levels in addition to lactate only we were able to be more precise in continuously determining which energy substrate was used. We calculated IAT using the concept of Dickhut et al. [41], one of several lactate threshold concepts that can be used to determine submaximal performance and has been proven sufficient for performance diagnostics [42,43].

All healthy recreational athletes aged 18 to 65 , who had performed their performance diagnostic test on a treadmill ergometer between 1 July 2013 and 1 February 2017 with valid data on serum $25(\mathrm{OH}) \mathrm{D}$ levels were included in the study. 25(OH)D levels were tested in separate laboratories individually prior to the performance test. The main method used was the protein binding immunoassay using “Elecsys ${ }^{\circledR}$ Vitamin D total II" (Roche Diagnostics AG, Rotkreuz, Schweiz), which has been shown to accurately measure $25(\mathrm{OH}) \mathrm{D}$ levels [44]. Patients who had had their blood taken over three months prior to their performance test were excluded. All patients who had performed their performance test on a cycle ergometer were excluded. To ensure valid data, only athletes following the protocol mentioned above were included in this study. A total of 581 healthy athletes ( 284 females and 297 males) were included (Tables 1 and 2). They were considered healthy as long as there were no medical contraindications for stress tests such as unstable cardiac disease or acute inflammatory disease $[45,46]$. Out of these only 224 female and 253 male athletes had their body fat measured. Body fat was therefore not included in further statistical analyses. Apart from body fat levels the data of all the athletes were complete. 
Table 1. Descriptive statistics of all female athletes.

\begin{tabular}{ccccccc}
\hline & N & Minimum & Maximum & Mean & SD & Variance \\
\hline Age & 284 & 18 & 65 & 38.66 & 9.82 & 96.51 \\
Bodyweight $(\mathrm{kg})$ & 284 & 45.1 & 99.4 & 63.42 & 9.12 & 83.24 \\
Height $(\mathrm{cm})$ & 284 & 152 & 188 & 166.91 & 6.13 & 37.62 \\
BMI $\left(\mathrm{kg} / \mathrm{m}^{2}\right)$ & 284 & 17.5 & 34.2 & 22.76 & 2.84 & 8.09 \\
$25(\mathrm{OH}) \mathrm{D}(\mathrm{ng} / \mathrm{mL})$ & 284 & 7.5 & 66.5 & 27.17 & 10.89 & 118.57 \\
Weekly training $(\mathrm{h})$ & 284 & 0 & 15 & 5.20 & 1.53 & 2.34 \\
$P_{\max }(\mathrm{km} / \mathrm{h})$ & 284 & 6.7 & 18.7 & 12.94 & 1.96 & 3.83 \\
$\mathrm{P}_{\text {submax }}(\mathrm{km} / \mathrm{h})$ & 284 & 5.3 & 16.2 & 10.02 & 1.40 & 1.95 \\
\hline
\end{tabular}

BMI: body mass index; 25(OH)D: 25-hydroxyvitamin D; maximal $\left(\mathrm{P}_{\max }\right)$ and submaximal physical performance $\left(\mathrm{P}_{\text {submax }}\right)$.

Table 2. Descriptive statistics of all male athletes.

\begin{tabular}{ccccccc}
\hline & N & Minimum & Maximum & Mean & SD & Variance \\
\hline Age & 297 & 18 & 64 & 40.54 & 9.16 & 83.95 \\
Bodyweight $(\mathrm{kg})$ & 297 & 47.6 & 149.4 & 80.12 & 11.43 & 130.71 \\
Height $(\mathrm{cm})$ & 297 & 155.0 & 198.0 & 180.40 & 6.71 & 45.04 \\
BMI $\left(\mathrm{kg} / \mathrm{m}^{2}\right)$ & 297 & 18 & 41.3 & 24.53 & 2.81 & 7.94 \\
$25(\mathrm{OH}) \mathrm{D}(\mathrm{ng} / \mathrm{mL})$ & 297 & 5.2 & 64.5 & 24.80 & 10.15 & 103.09 \\
Weekly training $(\mathrm{h})$ & 297 & 2 & 20 & 6.21 & 2.21 & 4.89 \\
$P_{\max }(\mathrm{km} / \mathrm{h})$ & 297 & 8.7 & 22.0 & 15.81 & 1.98 & 3.92 \\
$\mathrm{P}_{\text {submax }}(\mathrm{km} / \mathrm{h})$ & 297 & 7.1 & 17.0 & 11.85 & 1.59 & 2.523 \\
\hline
\end{tabular}

BMI: body mass index; 25(OH)D: 25-hydroxyvitamin $\mathrm{D}$; maximal $\left(\mathrm{P}_{\max }\right)$ and submaximal physical performance $\left(\mathrm{P}_{\text {submax }}\right)$.

Several statistical tests were performed to test whether vitamin D levels are associated with $P_{\max }$ or $P_{\text {submax }}$. Males and females were analysed separately because the expected high variance in performance parameters would distort the results for possible correlations with 25(OH)D.

For further statistical analysis calculated BMI levels were divided into two groups of normal $\left(\mathrm{BMI}<25 \mathrm{~kg} / \mathrm{m}^{2}\right)$ and overweight/obese (BMI $\left.\geq 25 \mathrm{~kg} / \mathrm{m}^{2}\right)$, and a cut off value of $25(\mathrm{OH}) \mathrm{D}$ levels of $20 \mathrm{ng} / \mathrm{mL}$ [35], was used to separate athletes according to their vitamin D levels into groups with sufficient and "insufficient" vitamin D status.

A two-tailed statistical significance was accepted at the $p<0.05$ level. Seasonal differences in 25(OH)D levels and $P_{\max }$ or $P_{\text {submax }}$ were calculated using an ANOVA. Unpaired $t$-tests were used to assess the association of $P_{\max }$ and $P_{\text {submax }}$ between groups of sufficient (serum $25(\mathrm{OH}) \mathrm{D}>20 \mathrm{ng} / \mathrm{mL}$ ) and "insufficient" (serum $25(\mathrm{OH}) \mathrm{D} \leq 20 \mathrm{ng} / \mathrm{mL}$ ) vitamin D status and to determine differences in $P_{\max }$, $\mathrm{P}_{\text {submax }}$ and serum $25(\mathrm{OH}) \mathrm{D}$ levels between athletes with normal BMI and overweight athletes as well as differences in $\mathrm{P}_{\max }$ and $\mathrm{P}_{\text {submax }}$ between smokers and non-smokers. Additionally, an ANCOVA was performed to test for influencing variables (age, BMI, WTH and smoking status). Simple associations between primary, secondary and exploratory parameters were tested by Pearson correlations. Finally, stepwise multiple regression analyses were performed to determine whether the obtained exploratory parameters affected the correlation between vitamin $\mathrm{D}$ levels and performance. Four models were created for $P_{\max }$ and $P_{\text {submax }}$ in male and female athletes, respectively. After performing regression analysis for $25(\mathrm{OH}) \mathrm{D}$ as an independent and $\mathrm{P}_{\max }$ and $\mathrm{P}_{\text {submax }}$ as dependent variables, consecutively, the following parameter were added to the model: age, weekly training hours, BMI and nicotine abuse.

There were no outliers in the data as assessed by inspection of boxplots. Most of the parameters were normally distributed as verified by the Kolmogorov-Smirnov test and inspection of histograms. For those parameters that did not show normal distribution additionally non-parametric tests were performed for comparison, with similar results. All analyses were performed with IBM @ SPSS software (Version 23, IBM Inc., Armonk, NY, USA). 


\section{Results}

Female athletes showed non-significantly higher serum 25(OH)D levels than male athletes (Figure 1). 75 females and 96 males had 25(OH)D levels $\leq 20 \mathrm{ng} / \mathrm{mL}$. Therefore, according to the cut off levels defined by the IOM out of all the included athletes $26 \%$ of females and $32 \%$ of males would have an "insufficient" vitamin D status. However, if our data were analysed according to the US Endocrinology Society guidelines $66 \%$ of females and $76 \%$ of males would have insufficient vitamin D levels $(\leq 30 \mathrm{ng} / \mathrm{mL})$.

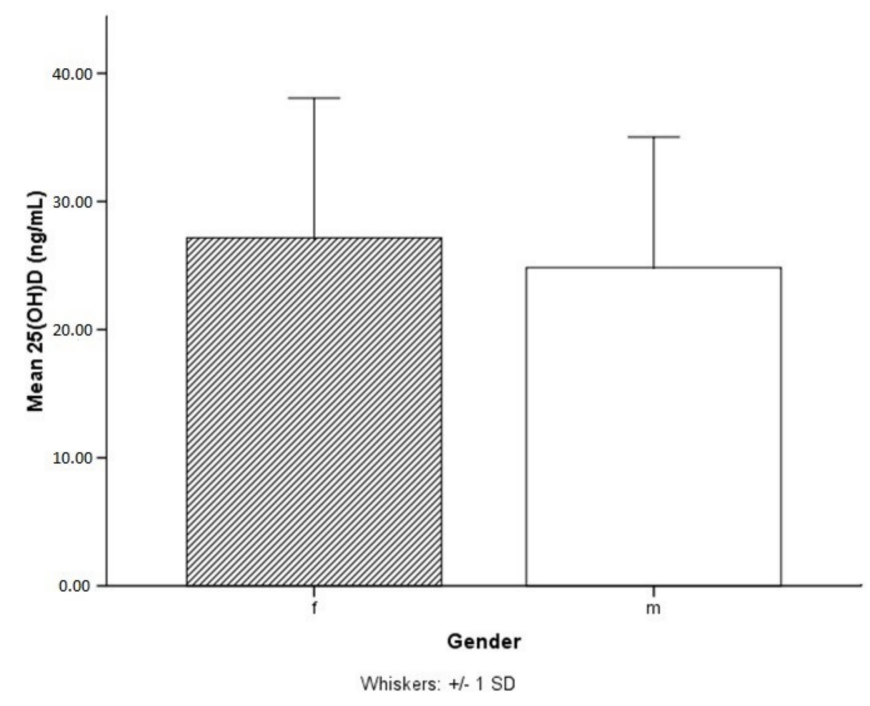

Figure 1. Mean serum 25(OH)D (25-hydroxyvitamin D) levels in females (f) with $27.17 \mathrm{ng} / \mathrm{mL}$ were found to be non-significantly higher than mean $25(\mathrm{OH}) \mathrm{D}$ levels in males $(\mathrm{m})$ with $24.80 \mathrm{ng} / \mathrm{mL}$.

As expected, our results showed that 25(OH)D levels varied significantly between seasons with lowest values in winter and highest values in summer in female $(\mathrm{F}=11.538, p=0.000)$ and male athletes $(\mathrm{F}=22.345, p=0.000)$, respectively (Figure 2$)$. Furthermore, our results showed that $57 \%$ percent of our athletes had vitamin D levels $\leq 30 \mathrm{ng} / \mathrm{mL}$ even during the summer months of July, August and September, however only $8 \%$ had levels $\leq 20 \mathrm{ng} / \mathrm{mL}$.

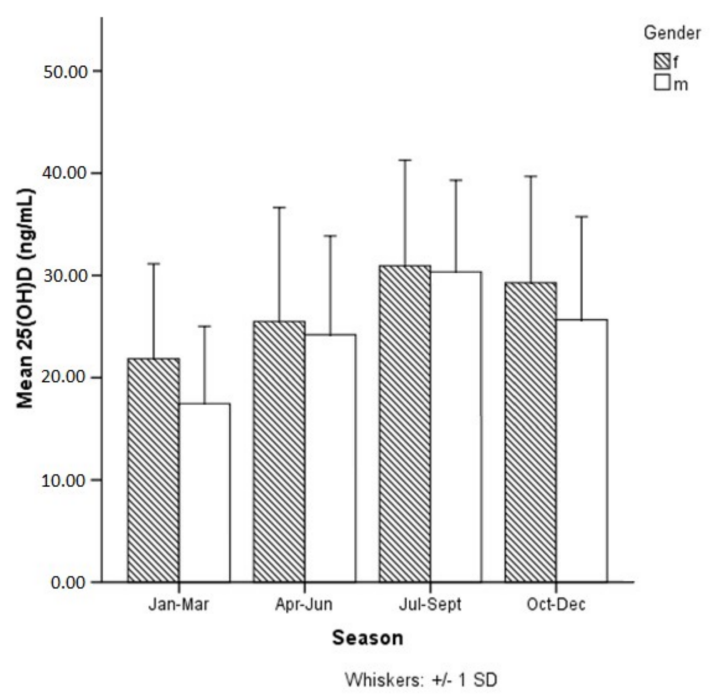

Figure 2. Significant variations in 25(OH)D (25-hydroxyvitamin $\mathrm{D})$ levels between seasons $(p=0.000)$.

There were no seasonal differences for $\mathrm{P}_{\max }$ and $\mathrm{P}_{\text {submax }}$ (data not shown) but male athletes with sufficient (>20ng/mL) 25(OH)D levels showed significantly higher $P_{\text {submax }}$ levels compared to those 
with levels $\leq 20 \mathrm{ng} / \mathrm{mL}$ (Figure 3). In females the difference in $\mathrm{P}_{\text {submax }}$ was insignificant $(p=0.08)$. Any detected differences between vitamin D groups $(\leq 20 \mathrm{ng} / \mathrm{mL}$ vs. $>20 \mathrm{ng} / \mathrm{mL})$ in $P_{\max }$ and $P_{\text {submax }}$ for both male and female athletes were insignificant when controlled for modifying variables (age, BMI, WTH, smoking status) (data not shown).

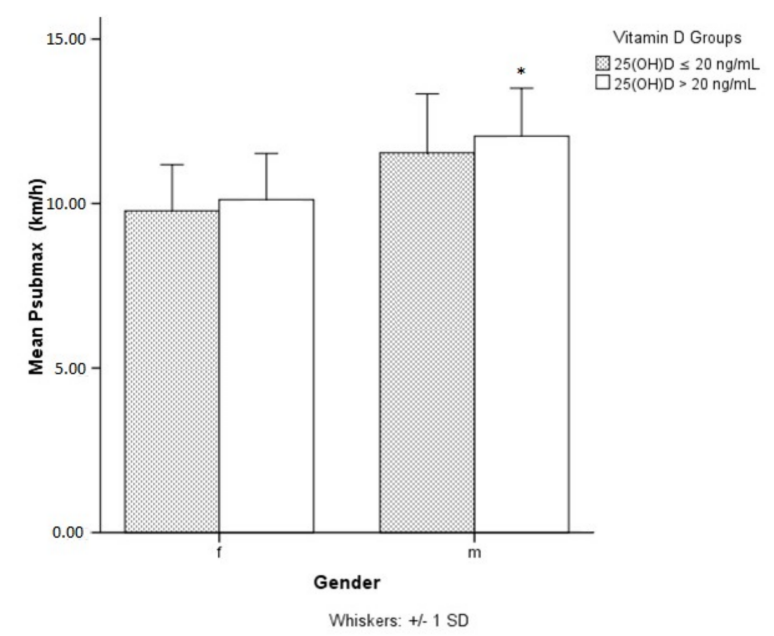

Figure 3. Significant differences $(p=0.045)$ in submaximal performance between groups of sufficient vitamin D status $(25(\mathrm{OH}) \mathrm{D}>20 \mathrm{ng} / \mathrm{mL})$ and insufficient vitamin D status $(25(\mathrm{OH}) \mathrm{D} \leq 20 \mathrm{ng} / \mathrm{mL})$ in males but not in females. 25(OH)D: 25-hydroxyvitamin D; * submaximal performance significantly higher in male athletes with $25(\mathrm{OH}) \mathrm{D}$ levels $>20 \mathrm{ng} / \mathrm{mL}$.

Concordant with other findings [47] $\mathrm{P}_{\max }$ and $\mathrm{P}_{\text {submax }}$ were significantly lower in overweight males compared to those with normal BMI $(p<0.001)$ with no significant difference in $25(\mathrm{OH}) \mathrm{D}$ levels between the two groups (data not presented). In female athletes we found significant differences in $\mathrm{P}_{\max }, \mathrm{P}_{\text {submax }}$ and $25(\mathrm{OH}) \mathrm{D}$ (Table 3$)$.

Table 3. Differences in $\mathrm{P}_{\max }, \mathrm{P}_{\text {submax }}$ and 25(OH)D levels between female athletes with normal and high BMI.

\begin{tabular}{cccccc}
\hline & $\mathbf{F}$ & $\boldsymbol{p}$-Value & BMI $\left(\mathbf{k g} / \mathbf{m}^{\mathbf{2}}\right)$ & $\mathbf{N}$ & Mean \pm SD \\
\hline \multirow{2}{*}{$\mathrm{P}_{\max }(\mathrm{km} / \mathrm{h})$} & \multirow{2}{*}{5.075} & \multirow{2}{*}{0.000} & $<25$ (normal) & 234 & $13.23 \pm 1.78$ \\
& & & $\geq 25$ (overweight) & 50 & $11.57 \pm 2.19$ \\
\hline \multirow{2}{*}{$\mathrm{P}_{\text {submax }}(\mathrm{km} / \mathrm{h})$} & \multirow{2}{*}{2.384} & \multirow{2}{*}{0.000} & $<25$ (normal) & 234 & $10.2 \pm 1.32$ \\
& & & $\geq 25$ (overweight) & 50 & $9.21 \pm 1.49$ \\
\hline \multirow{2}{*}{$25(\mathrm{OH}) \mathrm{D}(\mathrm{ng} / \mathrm{mL})$} & \multirow{2}{*}{0.445} & \multirow{2}{*}{0.012} & $<25$ (normal) & 234 & $27.91 \pm 10.68$ \\
& & & $\geq 25$ (overweight) & 50 & $23.67 \pm 11.29$ \\
\hline
\end{tabular}

$t$-test for BMI (normal and overweight) groups of normal weight $(<25)$ and overweight $(\geq 25)$ as independent variables; 25(OH)D: 25-hydroxyvitamin $\mathrm{D}$.

No significant differences in $\mathrm{P}_{\max }$ and $\mathrm{P}_{\text {submax }}$ were found between smokers and non-smokers in male and female athletes (data not shown).

In female athletes significant correlations at the $p=0.05$ level were found for $25(\mathrm{OH}) \mathrm{D}$ and $\mathrm{P}_{\max }$ $(\mathrm{r}=0.143)$ as well as for $25(\mathrm{OH}) \mathrm{D}$ and $\mathrm{P}_{\text {submax }}(\mathrm{r}=0.141)$, while in male athletes only the correlation between $25(\mathrm{OH}) \mathrm{D}$ and $\mathrm{P}_{\text {submax }}(\mathrm{r}=0.139)$ reached the level of significance. Even though significant correlations were shown between $25(\mathrm{OH}) \mathrm{D}$ and $\mathrm{P}_{\max }$ and $\mathrm{P}_{\text {submax }}$ in female athletes and between 25(OH)D and $P_{\max }$ in male athletes, correlation coefficients were low. Furthermore, after applying a Bonferroni correction for multiple testing with a new $\mathrm{p}$ value of $<0.001$ only few correlations would remain significant (Tables 4 and 5). 
Table 4. Pearson correlations of included variables in female athletes.

\begin{tabular}{|c|c|c|c|c|c|c|c|c|c|}
\hline & & $\begin{array}{l}\text { VitD } \\
\text { Groups }\end{array}$ & $\begin{array}{l}\text { 25(OH)D } \\
\text { (ng/mL) }\end{array}$ & $\begin{array}{c}P_{\max } \\
(\mathbf{k m} / \mathbf{h})\end{array}$ & $\begin{array}{c}P_{\text {submax }} \\
(\mathrm{km} / \mathrm{h})\end{array}$ & Age & WTH (h) & BMI & Nicotine \\
\hline \multirow{2}{*}{$\begin{array}{l}\text { VitD } \\
\text { groups }\end{array}$} & \multirow{2}{*}{$\begin{array}{l}\text { Pearson's r } \\
p \text {-value }\end{array}$} & \multirow[t]{2}{*}{1} & 0.680 & 0.087 & 0.104 & -0.054 & 0.125 & -0.205 & -0.106 \\
\hline & & & 0.000 & 0.143 & 0.080 & 0.364 & 0.036 & 0.000 & 0.075 \\
\hline \multirow{2}{*}{$\begin{array}{l}25(\mathrm{OH}) \mathrm{D} \\
(\mathrm{ng} / \mathrm{mL})\end{array}$} & \multirow{2}{*}{$\begin{array}{l}\text { Pearson's r } \\
p \text {-value }\end{array}$} & 0.680 & 1 & 0.143 & 0.141 & -0.051 & 0.230 & -0.149 & -0.164 \\
\hline & & 0.000 & & 0.016 & 0.017 & 0.390 & 0.000 & 0.012 & 0.006 \\
\hline \multirow{2}{*}{$\begin{array}{c}\mathrm{P}_{\max } \\
(\mathrm{km} / \mathrm{h})\end{array}$} & \multirow{2}{*}{$\begin{array}{l}\text { Pearson's r } \\
p \text {-value }\end{array}$} & 0.087 & 0.143 & 1 & 0.897 & -0.391 & 0.400 & -0.324 & -0.100 \\
\hline & & 0.143 & 0.016 & & 0.000 & 0.000 & 0.000 & 0.000 & 0.092 \\
\hline \multirow{2}{*}{$\begin{array}{l}\mathrm{P}_{\text {submax }} \\
(\mathrm{km} / \mathrm{h})\end{array}$} & \multirow{2}{*}{$\begin{array}{l}\text { Pearson's r } \\
p \text {-value }\end{array}$} & 0.104 & 0.141 & 0.897 & 1 & -0.260 & 0.439 & -0.270 & -0.135 \\
\hline & & 0.080 & 0.017 & 0.000 & & 0.000 & 0.000 & 0.000 & 0.023 \\
\hline \multirow{2}{*}{ Age } & \multirow{2}{*}{$\begin{array}{c}\text { Pearson's r } \\
p \text {-value }\end{array}$} & -0.054 & -0.051 & -0.391 & -0.260 & 1 & -0.160 & 0.175 & 0.006 \\
\hline & & 0.364 & 0.390 & 0.000 & 0.000 & & 0.007 & 0.003 & 0.920 \\
\hline \multirow{2}{*}{$\begin{array}{l}\text { WTH } \\
\text { (h) }\end{array}$} & \multirow{2}{*}{$\begin{array}{l}\text { Pearson's r } \\
p \text {-value }\end{array}$} & 0.125 & 0.230 & 0.400 & 0.439 & -0.160 & 1 & -0.132 & -0.014 \\
\hline & & 0.036 & 0.000 & 0.000 & 0.000 & 0.007 & & 0.026 & 0.809 \\
\hline \multirow{2}{*}{ BMI } & \multirow{2}{*}{$\begin{array}{c}\text { Pearson's r } \\
p \text {-value }\end{array}$} & -0.205 & -0.149 & -0.324 & -0.270 & 0.175 & -0.132 & 1 & -0.008 \\
\hline & & 0.000 & 0.012 & 0.000 & 0.000 & 0.003 & 0.026 & & 0.887 \\
\hline \multirow{2}{*}{ Nicotine } & \multirow{2}{*}{$\begin{array}{c}\text { Pearson's r } \\
p \text {-value }\end{array}$} & -0.106 & -0.164 & -0.100 & -0.135 & 0.006 & -0.014 & -0.008 & 1 \\
\hline & & 0.075 & 0.006 & 0.092 & 0.023 & 0.920 & 0.809 & 0.887 & \\
\hline
\end{tabular}

VitD groups ( $\leq 20 \mathrm{ng} / \mathrm{mL},>20 \mathrm{ng} / \mathrm{mL}) ; 25(\mathrm{OH}) \mathrm{D}$ : 25-hydroxyvitamin D; WTH: weekly training hours; BMI (normal and overweight); Nicotine (abuse yes or no). All findings significant at the $<0.001$ level are bold.

Table 5. Pearson correlations of included variables in male athletes.

\begin{tabular}{|c|c|c|c|c|c|c|c|c|c|}
\hline & & $\begin{array}{c}\text { VitD } \\
\text { Groups }\end{array}$ & $\begin{array}{l}\text { 25(OH)D } \\
\text { (ng/mL) }\end{array}$ & $\begin{array}{c}P_{\max } \\
(\mathrm{km} / \mathrm{h})\end{array}$ & $\begin{array}{c}P_{\text {submax }} \\
(\mathrm{km} / \mathrm{h})\end{array}$ & Age & WTH (h) & BMI & Nicotine \\
\hline \multirow{2}{*}{$\begin{array}{l}\text { VitD } \\
\text { groups }\end{array}$} & \multirow{2}{*}{$\begin{array}{c}\text { Pearson's r } \\
p \text {-value }\end{array}$} & \multirow[t]{2}{*}{1} & 0.686 & 0.077 & 0.125 & 0.071 & 0.093 & -0.087 & -0.026 \\
\hline & & & 0.000 & 0.184 & 0.031 & 0.220 & 0.109 & 0.134 & 0.654 \\
\hline \multirow{2}{*}{$\begin{array}{l}\text { 25(OH)D } \\
\text { (ng/mL) }\end{array}$} & \multirow{2}{*}{$\begin{array}{c}\text { Pearson's r } \\
p \text {-value }\end{array}$} & 0.686 & 1 & 0.102 & 0.139 & 0.116 & -0.013 & -0.029 & 0.000 \\
\hline & & 0.000 & & 0.080 & 0.017 & 0.045 & 0.817 & 0.619 & 0.996 \\
\hline \multirow{2}{*}{$\begin{array}{c}P_{\max } \\
(\mathrm{km} / \mathrm{h})\end{array}$} & \multirow{2}{*}{$\begin{array}{c}\text { Pearson's r } \\
p \text {-value }\end{array}$} & 0.077 & 0.102 & 1 & 0.851 & -0.378 & 0.401 & -0.355 & -0.065 \\
\hline & & 0.184 & 0.080 & & 0.000 & 0.000 & 0.000 & 0.000 & 0.267 \\
\hline \multirow{2}{*}{$\begin{array}{c}P_{\text {submax }} \\
(\mathbf{k m} / \mathrm{h})\end{array}$} & \multirow{2}{*}{$\begin{array}{c}\text { Pearson's r } \\
p \text {-value }\end{array}$} & 0.125 & 0.139 & 0.851 & 1 & -0.168 & 0.452 & -0.316 & -0.086 \\
\hline & & 0.031 & 0.017 & 0.000 & & 0.004 & 0.000 & 0.000 & 0.137 \\
\hline \multirow{2}{*}{ Age } & \multirow{2}{*}{$\begin{array}{c}\text { Pearson's r } \\
p \text {-value }\end{array}$} & 0.071 & 0.116 & -0.378 & -0.168 & 1 & -0.113 & 0.087 & -0.135 \\
\hline & & 0.220 & 0.045 & 0.000 & 0.004 & & 0.052 & 0.135 & 0.020 \\
\hline \multirow{2}{*}{$\begin{array}{c}\text { WTH } \\
\text { (h) }\end{array}$} & \multirow{2}{*}{$\begin{array}{c}\text { Pearson's r } \\
p \text {-value }\end{array}$} & 0.093 & -0.013 & 0.401 & 0.452 & -0.113 & 1 & -0.146 & -0.067 \\
\hline & & 0.109 & 0.817 & 0.000 & 0.000 & 0.052 & & 0.012 & 0.252 \\
\hline \multirow{2}{*}{ BMI } & \multirow{2}{*}{$\begin{array}{c}\text { Pearson's r } \\
p \text {-value }\end{array}$} & -0.087 & -0.029 & -0.355 & -0.316 & 0.087 & -0.146 & 1 & 0.105 \\
\hline & & 0.134 & 0.619 & 0.000 & 0.000 & 0.135 & 0.012 & & 0.070 \\
\hline \multirow[b]{2}{*}{ Nicotine } & \multirow{2}{*}{$\begin{array}{l}\text { Pearson's r } \\
p \text {-value }\end{array}$} & -0.026 & 0.000 & -0.065 & -0.086 & -0.135 & -0.067 & 0.105 & 1 \\
\hline & & 0.654 & 0.996 & 0.267 & 0.137 & 0.020 & 0.252 & 0.070 & \\
\hline
\end{tabular}

VitD groups ( $\leq 20 \mathrm{ng} / \mathrm{mL},>20 \mathrm{ng} / \mathrm{mL}) ; 25(\mathrm{OH}) \mathrm{D}$ : 25-hydroxyvitamin $\mathrm{D}$; WTH: weekly training hours; BMI (normal and overweight); Nicotine (abuse yes or no). All findings significant at the $<0.001$ level are bold.

In multiple regression analyses different models were used to study the effect of WTH, BMI and smoking status on the association between 25(OH)D and performance (Tables 6 and 7). Unexpectedly, the results differed greatly between males and females. In male athletes the correlation between 25(OH)D and $\mathrm{P}_{\max }$ became more significant in model 2 once age was added as an independent parameter $(p=0.006)$ (Table 7). Further inclusion of other covariates slightly increased the significance. The correlation between $25(\mathrm{OH}) \mathrm{D}$ and $\mathrm{P}_{\text {submax }}$ was already significant in model $1(p=0.017)$ and remained significant. In female athletes the significant correlation between $25(\mathrm{OH}) \mathrm{D}$ and $\mathrm{P}_{\max }$ disappeared after adding WTH to the analysis (Table 6). After adding BMI and nicotine abuse 
in model 4 the correlation becomes even more insignificant $(p=0.923)$. Multiple regression analysis for $\mathrm{P}_{\text {submax }}$ and vitamin $\mathrm{D}$ in female athletes revealed similar results.

Table 6. Associations between $25(\mathrm{OH}) \mathrm{D}$ levels and $\mathrm{P}_{\max } / \mathrm{P}_{\text {submax }}$ in female athletes.

\begin{tabular}{|c|c|c|c|c|}
\hline & \multicolumn{2}{|c|}{$\beta$} & \multicolumn{2}{|c|}{$p$-Value } \\
\hline & $\mathbf{P}_{\max }$ & $\mathbf{P}_{\text {submax }}$ & $\mathbf{P}_{\max }$ & $\mathbf{P}_{\text {submax }}$ \\
\hline \multicolumn{5}{|c|}{ Model 1 (unadjusted) } \\
\hline $25(\mathrm{OH}) \mathrm{D}$ & 0.143 & 0.141 & 0.016 & 0.017 \\
\hline \multicolumn{5}{|c|}{ Model 2 (adjusted for age) } \\
\hline $25(\mathrm{OH}) \mathrm{D}$ & 0.124 & 0.128 & 0.024 & 0.026 \\
\hline \multicolumn{5}{|c|}{ Model 3 (adjusted for age + WTH) } \\
\hline $25(\mathrm{OH}) \mathrm{D}$ & 0.049 & 0.039 & 0.349 & 0.467 \\
\hline \multicolumn{5}{|c|}{ Model 4 (adjusted for age $+\mathrm{WTH}+\mathrm{BMI}+$ nicotine abuse) } \\
\hline $25(\mathrm{OH}) \mathrm{D}$ & 0.005 & -0.007 & 0.923 & 0.903 \\
\hline
\end{tabular}

Table 7. Associations between $25(\mathrm{OH}) \mathrm{D}$ levels and $\mathrm{P}_{\max } / \mathrm{P}_{\text {submax }}$ in male athletes.

\begin{tabular}{lcccc}
\hline & \multicolumn{2}{c}{$\beta$} & \multicolumn{2}{c}{$p$-Value } \\
\cline { 2 - 5 } & $\mathbf{P}_{\text {max }}$ & $\mathbf{P}_{\text {submax }}$ & $\mathbf{P}_{\text {max }}$ & $\mathbf{P}_{\text {submax }}$ \\
\hline $\begin{array}{l}\text { Model 1 (unadjusted) } \\
\text { 25(OH)D }\end{array}$ & 0.102 & 0.139 & 0.080 & 0.017 \\
\hline $\begin{array}{l}\text { Model 2 (adjusted for age) } \\
\text { 25(OH)D }\end{array}$ & 0.148 & 0.006 & 0.005 \\
\hline $\begin{array}{l}\text { Model 3 (adjusted for age + WTH) } \\
\text { 25(OH)D }\end{array}$ & 0.148 & 0.160 & 0.002 \\
\hline $\begin{array}{l}\text { Model 4 (adjusted for age }+ \text { WTH }+ \text { BMI + nicotine abuse) } \\
\text { 25(OH)D } \\
0.138\end{array}$ & 0.152 & 0.161 & 0.003 \\
\hline
\end{tabular}

\section{Discussion}

The major findings of our study are that there is a small but significant correlation between vitamin D status and parameters of endurance performance, especially in male athletes. In female athletes the correlation seems to be influenced to a greater extent by other biological and lifestyle factors like WTH, BMI and nicotine abuse. Accordingly, we found significant correlations between 25(OH)D and WTH as well as BMI in females only. Compared to earlier studies that have yielded controversial results as to whether vitamin D deficiency is linked to physical performance in athletes our findings show only a mild significant correlation between 25(OH)D and performance parameters. Most studies have shown a correlation between vitamin D status and muscle strength parameters [22-25,48], it is therefore possible that vitamin $\mathrm{D}$ has a greater effect on muscle performance than it has on endurance parameters.

A systematic review and meta-analysis from 2014 including 23 articles with 2313 athletes from the UK, Ireland, Spain, France, the USA, Australia and Middle Eastern Countries showed a prevalence rate of $56 \%$ for vitamin D inadequacy (serum $25(\mathrm{OH}) \mathrm{D}$ levels $<80 \mathrm{nmol} / \mathrm{L}=32 \mathrm{ng} / \mathrm{mL}$ ) [34]. Compared with these results, our findings revealed even higher prevalence rates. Furthermore, when dividing our data into groups of athletes with sufficient and insufficient vitamin D status, the choice of cut-off levels markedly influences the prevalence of athletes with vitamin D deficiency. The percentages of athletes with sufficient and insufficient vitamin D status are almost exactly reversed when cut-off levels are changed from 20 to $30 \mathrm{ng} / \mathrm{mL}$

The issue of optimal vitamin D cut-off levels has been intensively discussed over the last decades and remains unsolved. For example, based on biochemical findings Heaney at el. suggested that optimal serum concentrations start at the turning point in $25(\mathrm{OH}) \mathrm{D}$ kinetics of $88 \mathrm{nmol} / \mathrm{L}$ $(35.2 \mathrm{ng} / \mathrm{mL}$ ) [49]. In terms of bone mineral density (BMD), lower-extremity function, falls, dental 
health and colorectal cancer prevention Bischoff-Ferrari et al. [3] found 25(OH)D concentrations to be most advantageous starting from $75 \mathrm{nmol} / \mathrm{L}$ with best concentrations between 90 and $100 \mathrm{nmol} / \mathrm{L}$ (36-40 ng/mL), hence also supporting the claim of a higher cut off level.

The German Nutrition Society [50] proposes a daily vitamin D intake of $20 \mu \mathrm{g}$ for adolescents and adults under 65 years and 20-25 $\mu \mathrm{g}$ per day for populations older than 65 years in case of absent endogenous vitamin D synthesis as the majority of people were found to achieve $25(\mathrm{OH}) \mathrm{D}$ levels $>50 \mathrm{nmol} / \mathrm{L}$ with a supplementary intake of $20 \mu \mathrm{g} / \mathrm{d}$ during the winter months in a study published in 2008 by Cashman et al. [51].

In our data an expected variance in vitamin D levels was observed throughout the seasons, but seasonal differences were detected in neither $\mathrm{P}_{\max }$ nor $\mathrm{P}_{\text {submax }}$. These findings stand partly contradictory to earlier findings that have detected significant differences in physical fitness parameter dependent on season or exposure to UVB radiation [52-57]. While our data include a sample of hobby athletes most of the cited studies have included a small number of elite athletes or have analysed other outcome parameter for physical performance (i.e., $\mathrm{VO}_{2} \max$, heart rate variability, strength). Direct comparison with these findings might therefore not be suitable to interpret our results.

In accordance with this, it is not surprising that we found no significant correlation between 25(OH)D and $P_{\max }$ for both male and female athletes. However, the findings for $P_{\text {submax }}$ revealed a small correlation that was significant in men and almost significant in women, suggesting that $P_{\text {submax }}$ and vitamin D levels might be linked in some way.

An interesting result was the significant correlation between $25(\mathrm{OH}) \mathrm{D}$ and WTH in female but not male athletes. One plausible explanation for this discrepancy could be that female athletes do more outdoor training. However, we did not find studies showing these gender specific differences in training habits. An earlier study by Sparling and Cureton revealed no significant differences in the effect of performance determining variables, like cardiorespiratory capacity, body fat and running economy on distance running performance between similarly trained males and females. The authors however found that body fat accounted for the greatest part of gender differences in running performance [58].

As opposed to male athletes, the data for female athletes also showed a slight significant negative correlation between $25(\mathrm{OH}) \mathrm{D}$ levels and BMI. There is a known difference in distribution of body mass between men and women. While the percentage of lean body mass in men is significantly higher, women have an average of 7-9\% higher amount of body fat [59]. A higher BMI in female athletes is therefore more likely to be associated with higher body fat. As vitamin D is mostly stored in adipose tissue, this might be a possible explanation for the negative correlation with BMI in female athletes [60]. Also, inhibition of adipogenesis by $1,25(\mathrm{OH})_{2} \mathrm{D}$ has been discussed [61]. VDR and hydroxylation enzymes have also been detected in adipose tissue indicating a possible regulative role of vitamin $\mathrm{D}$ [11]. Whether vitamin $\mathrm{D}$ levels are a consequence of higher body fat or might possibly contribute to it is not clear.

The most prominent gender differences were shown in multiple regression analyses. In male athletes, for both maximal and submaximal performance, age, weekly training hours and BMI seem to stabilize the correlation with 25(OH)D. By contrast, the significant correlation between 25(OH)D and $\mathrm{P}_{\text {submax }}$ or $25(\mathrm{OH}) \mathrm{D}$ and $\mathrm{P}_{\max }$ in female athletes is hardly influenced by age but is reduced remarkably by weekly training hours and BMI. These findings match the correlations mentioned above. Seemingly, weekly training hours and BMI in female athletes affect 25(OH)D levels in a way that decreases their effect on performance. Although a specific reason for this effect remains unclear, different factors might have played a role like more relevant body weight changes in women compared to men or differences in health awareness that lead to higher supplementation of vitamin D. Considering that elite athletes in particular have been found to rely on supplementation to reach their required intake for several minerals and vitamins [62] it cannot be ruled out that athletes who do more training take more supplementation and might therefore show a better performance. However, given the cross-sectional 
study design it is not possible to evaluate causal relationships in this triangle. Nevertheless, the primary aim of this study was to detect correlations between vitamin D levels and performance.

Other gender specific factors that should be considered to influence the relationship between vitamin $\mathrm{D}$ and performance include biochemical factors, like hormonal differences. For example, Heaney et al. reported that vitamin D binding protein (DBP) levels are increased during pregnancy and estrogen therapy [49]. However, due to the tight self-regulation through feedback mechanisms the concentration of free $1,25(\mathrm{OH})_{2} \mathrm{D}$ does not change. Intracellular vitamin $\mathrm{D}$ binding proteins (IDBPs) on the other hand directly modify intracellular vitamin $\mathrm{D}$ pathways by mediating the transport of $25(\mathrm{OH}) \mathrm{D}$ to mitochondrial $1 \alpha$-hydroxylase and are also known to bind estradiol. If higher estradiol levels lead to competitive replacement of $25(\mathrm{OH}) \mathrm{D}$ at the binding site, this could result in gender differences in vitamin D metabolism. Further studies would be needed to investigate this on a molecular level.

Similarly, two studies have found gender related differences in FGF-23 in infants $[63,64]$. Considering the newest finding on the role of FGF-23 in vitamin D regulation [14], the gender differences found might be partly due to this connection. However another study group identified significant associations between FGF-23 and age but not gender [65]. Recent genomic investigations by Miettinen et al. [66] showed that age is involved in the association between SPNs and $25(\mathrm{OH}) \mathrm{D}$, however no significant differences for gender were detected.

The main limitation in our study is that no interpretation on causality is possible, as is the case in all observational studies. In terms of data it also must be stated that the included measurements of serum 25(OH)D levels have been made at several individual laboratories and therefore no standardized measurement method could be ensured. However, all measurements have been undertaken in qualified and listed laboratories in Vienna, thus guaranteeing certified quality.

\section{Conclusions}

To conclude, the effects of vitamin D on muscle and physical performance are a topic still under investigation. While numerous studies have concentrated on specific targets of vitamin D metabolites and their intracellular effects, the definite consequences of those effects remain unclear in many cases. Observational studies that have been conducted have shown that vitamin D status might correlate with several aspects of physical performance but need to be followed by randomized controlled trials with sufficient sample size, predetermined cut-off levels and precise research aims. Moreover, as $25(\mathrm{OH}) \mathrm{D}$ cut-off levels determine the necessity to prescribe vitamin D supplementation in daily practice, a consensus in this field is sorely needed. Future studies might aim directly at answering the question whether vitamin D levels of 20 or $30 \mathrm{ng} / \mathrm{mL}$ make a difference in performance as well as many other health outcome parameters.

Author Contributions: Conceptualization, C.Z. and C.E.; data processing: C.Z.; statistics: C.E.; writing and visualization, C.Z.; review and editing, C.E., R.F. and G.S.; supervision, C.E.

Funding: This research received no external funding.

Acknowledgments: We would like to thank the whole team of "Sportordination" for providing the data that was used in the present study as well as for their professional insights and answers to any questions that arouse.

Conflicts of Interest: The authors declare no conflict of interest.

\section{References}

1. Holick, M.F. The vitamin D deficiency pandemic: Approaches for diagnosis, treatment and prevention. Rev. Endocr. Metab. Disord. 2017, 18, 153-165. [CrossRef] [PubMed]

2. Lips, P. Vitamin D physiology. Prog. Biophys. Mol. Biol. 2006, 92, 4-8. [CrossRef] [PubMed]

3. Bischoff-Ferrari, H.A.; Giovannucci, E.; Willett, W.C.; Dietrich, T.; Dawson-Hughes, B. Estimation of optimal serum concentrations of 25-hydroxyvitamin D for multiple health outcomes. Am. J. Clin. Nutr. 2006, 84, 18-28. [CrossRef] 
4. Murad, M.H.; Elamin, K.B.; Abu Elnour, N.O.; Elamin, M.B.; Alkatib, A.A.; Fatourechi, M.M.; Almandoz, J.P.; Mullan, R.J.; Lane, M.A.; Liu, H.; et al. Clinical review: The effect of vitamin D on falls: A systematic review and meta-analysis. J. Clin. Endocrinol. Metab. 2011, 96, 2997-3006. [CrossRef] [PubMed]

5. Garland, C.F.; Garland, F.C.; Gorham, E.D.; Lipkin, M.; Newmark, H.; Mohr, S.B.; Holick, M.F. The Role of Vitamin D in Cancer Prevention. Am. J. Public Health 2006, 96, 252-261. [CrossRef] [PubMed]

6. Ekmekcioglu, C.; Haluza, D.; Kundi, M. 25-Hydroxyvitamin D Status and Risk for Colorectal Cancer and Type 2 Diabetes Mellitus: A Systematic Review and Meta-Analysis of Epidemiological Studies. Int. J. Environ. Res. Public Health 2017, 14, 127. [CrossRef] [PubMed]

7. Hyppönen, E.; Läärä, E.; Reunanen, A.; Järvelin, M.-R.; Virtanen, S.M. Intake of vitamin D and risk of type 1 diabetes: A birth-cohort study. Lancet 2011, 358, 1500-1503. [CrossRef]

8. Cantorna, M.T.; Zhu, Y.; Froicu, M.; Wittke, A. Vitamin D status, 1,25-dihydroxyvitamin D3, and the immune system. Am. J. Clin. Nutr. 2004, 80, 1717S-1720S. [CrossRef]

9. McAlindon, T.E.; Felson, D.T.; Zhang, Y.; Hannan, M.T.; Aliabadi, P.; Weissman, B.; Rush, D.; Wilson, P.W.; Jacques, P. Relation of dietary intake and serum levels of vitamin D to progression of osteoarthritis of the knee among participants in the Framingham Study. Ann. Intern. Med. 1996, 125, 353-359. [CrossRef]

10. Burgaz, A.; Orsini, N.; Larsson, S.C.; Wolk, A. Blood 25-hydroxyvitamin D concentration and hypertension: A meta-analysis. J. Hypertens. 2011, 29, 636-645. [CrossRef]

11. Earthman, C.P.; Beckman, L.M.; Masodkar, K.; Sibley, S.D. The link between obesity and low circulating 25-hydroxyvitamin D concentrations: Considerations and implications. Int. J. Obes. 2012, 36, 387-396. [CrossRef] [PubMed]

12. Skaaby, T.; Husemoen, L.L.; Pisinger, C.; Jørgensen, T.; Thuesen, B.H.; Fenger, M.; Linneberg, A. Vitamin D status and changes in cardiovascular risk factors: A prospective study of a general population. Cardiology 2012, 123, 62-70. [CrossRef] [PubMed]

13. Stephensen, C.B.; Zerofsky, M.; Burnett, D.J.; Lin, Y.P.; Hammock, B.D.; Hall, L.M.; McHugh, T. Ergocalciferol from Mushrooms or Supplements Consumed with a Standard Meal Increases 25-Hydroxyergocalciferol but Decreases 25-Hydroxycholecalciferol in the Serum of Healthy Adults. J. Nutr. 2012, 142, 1246-1252. [CrossRef] [PubMed]

14. Dusso, A.S.; Brown, A.J.; Slatopolsky, E. Vitamin D. AJP Ren. Physiol. 2005, 289, F8-F28. [CrossRef] [PubMed]

15. Holick, M.F. Vitamin D deficiency. N. Engl. J. Med. 2007, 357, 266-281. [CrossRef] [PubMed]

16. Girgis, C.M.; Clifton-Bligh, R.J.; Hamrick, M.W.; Holick, M.F.; Gunton, J.E. The roles of vitamin D in skeletal muscle: Form, function, and metabolism. Endocr. Rev. 2013, 34, 33-83. [CrossRef] [PubMed]

17. Halfon, M.; Phan, O.; Theta, D. Vitamin D: A review on its effects on muscle strength, the risk of fall, and frailty. Biomed Res. Int. 2015, 2015. [CrossRef] [PubMed]

18. Tomlinson, P.B.; Joseph, C.; Angioi, M. Effects of vitamin D supplementation on upper and lower body muscle strength levels in healthy individuals. A systematic review with meta-analysis. J. Sci. Med. Sport 2014, 18, 575-580. [CrossRef]

19. Bischoff-Ferrari, H.A.; Dietrich, T.; Orav, E.J.; Hu, F.B.; Zhang, Y.; Karlson, E.W.; Dawson-Hughes, B. Higher 25-hydroxyvitamin D concentrations are associated with better lower-extremity function in both active and inactive persons aged $>$ or $=60 \mathrm{y}$. Am. J. Clin. Nutr. 2004, 80, 752-758. [CrossRef]

20. Kukuljan, S.; Nowson, C.A.; Sanders, K.M.; Nicholson, G.C.; Seibel, M.J.; Salmon, J.; Daly, R.M. Independent and Combined Effects of Calcium-Vitamin $\mathrm{D}_{3}$ and Exercise on Bone Structure and Strength in Older Men: An 18-Month Factorial Design Randomized Controlled Trial. J. Clin. Endocrinol. Metab. 2011, 96, 955-963. [CrossRef]

21. Kenny, A.M.; Biskup, B.; Robbins, B.; Marcella, G.; Burleson, J.A. Effects of vitamin D supplementation on strength, physical function, and health perception in older, community-dwelling men. J. Am. Geriatr. Soc. 2003, 51, 1762-1767. [CrossRef] [PubMed]

22. Gupta, R.; Sharma, U.; Gupta, N.; Kalaivani, M.; Singh, U.; Guleria, R.; Jagannathan, N.R.; Goswami, R. Effect of cholecalciferol and calcium supplementation on muscle strength and energy metabolism in vitamin D-deficient Asian Indians: A randomized, controlled trial. Clin. Endocrinol. 2010, 73, 445-451. [CrossRef] [PubMed]

23. Kalliokoski, P.; Bergqvist, Y.; Löfvander, M. Physical performance and 25-hydroxyvitamin D: A cross-sectional study of pregnant Swedish and Somali immigrant women and new mothers. BMC Pregnancy Childbirth 2013, 13, 237. [CrossRef] [PubMed] 
24. Fitzgerald, J.S.; Peterson, B.J.; Warpeha, J.M.; Johnson, S.C.; Ingraham, S.J. Association Between Vitamin D Status and Maximal-Intensity Exercise Performance in Junior and Collegiate Hockey Players. J. Strength Cond. Res. 2015, 29, 2513-2521. [CrossRef] [PubMed]

25. Wyon, M.A.; Koutedakis, Y.; Wolman, R.; Nevill, A.M.; Allen, N. The influence of winter vitamin D supplementation on muscle function and injury occurrence in elite ballet dancers: A controlled study. J. Sci. Med. Sport 2014, 17, 8-12. [CrossRef]

26. Close, G.L.; Russell, J.; Cobley, J.N.; Owens, D.J.; Wilson, G.; Gregson, W.; Fraser, W.D.; Morton, J.P. Assessment of vitamin D concentration in non-supplemented professional athletes and healthy adults during the winter months in the UK: Implications for skeletal muscle function. J. Sports Sci. 2013, 31, 344-353. [CrossRef]

27. Sinha, A.; Hollingsworth, K.G.; Ball, S.; Cheetham, T. Improving the vitamin D status of vitamin D deficient adults is associated with improved mitochondrial oxidative function in skeletal muscle. J. Clin. Endocrinol. Metab. 2013, 98, E509-E513. [CrossRef]

28. Barker, T.; Schneider, E.D.; Dixon, B.M.; Henriksen, V.T.; Weaver, L.K. Supplemental vitamin D enhances the recovery in peak isometric force shortly after intense exercise. Nutr. Metab. 2013, 10, 69. [CrossRef]

29. Marantes, I.; Achenbach, S.J.; Atkinson, E.J.; Khosla, S.; Melton, L.J., 3rd; Amin, S. Is vitamin D a determinant of muscle mass and strength? J. Bone Miner. Res. 2011, 26, 2860-2871. [CrossRef]

30. Flueck, J.; Schlaepfer, M.; Perret, C. Effect of 12-Week Vitamin D Supplementation on 25[OH]D Status and Performance in Athletes with a Spinal Cord Injury. Nutrients 2016, 8, 586. [CrossRef]

31. Owens, D.J.; Webber, D.; Impey, S.G.; Tang, J.; Donovan, T.F.; Fraser, W.D.; Morton, J.P.; Close, G.L. Vitamin D supplementation does not improve human skeletal muscle contractile properties in insufficient young males. Eur. J. Appl. Physiol. 2014, 114, 1309-1320. [CrossRef]

32. Close, G.L.; Leckey, J.; Patterson, M.; Bradley, W.; Owens, D.J.; Fraser, W.D.; Morton, J.P. The effects of vitamin $\mathrm{D}(3)$ supplementation on serum total $25[\mathrm{OH}] \mathrm{D}$ concentration and physical performance: A randomised dose-response study. Br. J. Sports Med. 2013, 47, 692-696. [CrossRef]

33. Hilger, J.; Friedel, A.; Herr, R.; Rausch, T.; Roos, F.; Wahl, D.A.; Pierroz, D.D.; Weber, P.; Hoffmann, K. A systematic review of vitamin D status in populations worldwide. Br. J. Nutr. 2014, 111, 23-45. [CrossRef]

34. Farrokhyar, F.; Tabasinejad, R.; Dao, D.; Peterson, D.; Ayeni, O.R.; Hadioonzadeh, R.; Bhandari, M. Prevalence of Vitamin D Inadequacy in Athletes: A Systematic-Review and Meta-Analysis. Sport Med. 2015, 45, 365-378. [CrossRef]

35. Ross, A.C.; Taylor, C.L.; Yaktine, A.L.; Del Valle, H.B. 5. Dietary Reference Intakes for Adequacy: Calcium and Vitamin D. In Dietary Reference Intakes for Calcium and Vitamin D; Institute of Medicine of the National Academies, The National Academies Press: Washington, DC, USA, 2011; ISBN 978-0-309-16394-1.

36. Holick, M.F.; Binkley, N.C.; Bischoff-Ferrari, H.A.; Gordon, C.M.; Hanley, D.A.; Heaney, R.P.; Murad, M.H.; Weaver, C.M.; Endocrine Society. Evaluation, treatment, and prevention of vitamin D deficiency: An Endocrine Society clinical practice guideline. J. Clin. Endocrinol. Metab. 2011, 96, 1911-1930. [CrossRef]

37. Roecker, K.; Schotte, O.; Niess, A.M.; Horstmann, T.; Dickhuth, H.H. Predicting competition performance in long-distance running by means of a treadmill test. Med. Sci. Sports Exerc. 1998, 30, 1552-1557. [CrossRef]

38. Prettin, S.; Roecker, K.; Ruehl, S.; Deibert, P.; Schumacher, Y.O.; Hirschmüller, A.; Dickhuth, H.H. Changes in blood lactate concentrations during different treadmill exercise test protocols. J. Sports Med. Phys. Fit. 2011, 51, 179-184.

39. Hall, M.M.; Rajasekaran, S.; Thomsen, T.W.; Peterson, A.R. Lactate: Friend or Foe. PM R 2016, 8, S8-S15. [CrossRef]

40. Gladden, L.B. Lactate metabolism: A new paradigm for the third millennium. J. Physiol. 2004, 558, 5-30. [CrossRef]

41. Dickhuth, H.H.; Yin, L.; Niess, A.; Röcker, K.; Mayer, F.; Heitkamp, H.C.; Horstmann, T. Ventilatory, lactate-derived and catecholamine thresholds during incremental treadmill running: Relationship and reproducibility. Int. J. Sports Med. 1999, 20, 122-127. [CrossRef]

42. Faude, O.; Meyer, T.; Urhausen, A.; Kindermann, W. Recovery training in cyclists: Ergometric, hormonal and psychometric findings. Scand. J. Med. Sci. Sports 2009, 19, 433-441. [CrossRef] [PubMed]

43. Beneke, R.; Leithäuser, R.M.; Ochentel, O. Blood lactate diagnostics in exercise testing and training. Int. J. Sports Physiol. Perform. 2011, 6, 8-24. [CrossRef] [PubMed] 
44. Freeman, J.; Wilson, K.; Spears, R.; Shalhoub, V.; Sibley, P. Performance evaluation of four 25-hydroxyvitamin D assays to measure 25-hydroxyvitamin D2. Clin. Biochem. 2015, 48, 1097-1104. [CrossRef] [PubMed]

45. Garner, K.K.; Pomeroy, W.; Arnold, J.J. Exercise Stress Testing: Indications and Common Questions. Am. Fam. Physician 2017, 96, 293-299. [PubMed]

46. Balady, G.J.; Weiner, D.A. Exercise testing for sports and the exercise prescription. Cardiol. Clin. 1987, 5, 183-196. [CrossRef]

47. Chen, C.J.; Liao, Y.H.; Lin, S.Y.; Yu, J.X.; Li, Z.J.; Lin, Y.C.; Chang, G.J.; Lin, C.H.; Wong, A.M. Diet-induced obesity accelerates blood lactate accumulation of rats in response to incremental exercise to maximum. Am. J. Physiol. Integr. Comp. Physiol. 2017, 313, R601-R607. [CrossRef] [PubMed]

48. Goswami, R.; Vatsa, M.; Sreenivas, V.; Singh, U.; Gupta, N.; Lakshmy, R.; Aggarwal, S.; Ganapathy, A.; Joshi, P.; Bhatia, H. Skeletal muscle strength in young Asian Indian females after vitamin D and calcium supplementation: A double-blind randomized controlled clinical trial. J. Clin. Endocrinol. Metab. 2012, 97, 4709-4716. [CrossRef] [PubMed]

49. Heaney, R.P.; Armas, L.A.; Shary, J.R.; Bell, N.H.; Binkley, N.; Hollis, B.W. 25-Hydroxylation of vitamin D3: Relation to circulating vitamin D3 under various input conditions. Am. J. Clin. Nutr. 2008, 87, 1738-1742. [CrossRef] [PubMed]

50. German Nutrition Society. New Reference Values for Vitamin D. Ann. Nutr. Metab. 2012, 60, $241-246$. [CrossRef] [PubMed]

51. Cashman, K.D.; Hill, T.R.; Lucey, A.J.; Taylor, N.; Seamans, K.M.; Muldowney, S.; Fitzgerald, A.P.; Flynn, A.; Barnes, M.S.; Horigan, G.; et al. Estimation of the dietary requirement for vitamin D in healthy adults. Am. J. Clin. Nutr. 2008, 88, 1535-1542. [CrossRef] [PubMed]

52. Erikssen, J.; Rodahl, K. Seasonal variation in work performance and heart rate response to exercise. A study of 1,835 middle-aged men. Eur. J. Appl. Physiol. Occup. Physiol. 1979, 42, 133-140. [CrossRef] [PubMed]

53. Kwarecki, K.; Golec, L.; Kłossowski, M.; Zuzewicz, K. Circannual rhythms of physical fitness and tolerance of hypoxic hypoxia. Acta Physiol. Pol. 1981, 32, 629-636. [PubMed]

54. Koch, H.; Raschka, C. Circannual period of physical performance analysed by means of standard cosinor analysis: A case report. Rom. J. Physiol. Physiol. Sci. 2000, 37, 51-58.

55. Svedenhag, J.; Sjödin, B. Physiological characteristics of elite male runners in and off-season. Can. J. Appl. Sport Sci. 1985, 10, 127-133. [PubMed]

56. Kristal-Boneh, E.; Froom, P.; Harari, G.; Malik, M.; Ribak, J. Summer-winter differences in 24 h variability of heart rate. J. Cardiovasc. Risk 2000, 7, 141-146. [CrossRef] [PubMed]

57. Cannell, J.J.; Hollis, B.W.; Sorenson, M.B.; Taft, T.N.; Anderson, J.J.B. Athletic performance and vitamin D. Med. Sci. Sports Exerc. 2009, 41, 1102-1110. [CrossRef] [PubMed]

58. Sparling, P.B.; Cureton, K.J. Biological determinants of the sex difference in 12-min run performance. Med. Sci. Sports Exerc. 1983, 15, 218-223. [CrossRef]

59. Lepers, R.; Knechtle, B.; Stapley, P.J. Trends in Triathlon Performance: Effects of Sex and Age. Sports Med. 2013, 43, 851-863. [CrossRef]

60. Wortsman, J.; Matsuoka, L.Y.; Chen, T.C.; Lu, Z.; Holick, M.F. Decreased bioavailability of vitamin D in obesity. Am. J. Clin. Nutr. 2000, 72, 690-693. [CrossRef]

61. Kong, J.; Li, Y.C. Molecular mechanism of 1,25-dihydroxyvitamin D3 inhibition of adipogenesis in 3T3-L1 cells. Am. J. Physiol. Endocrinol. Metab. 2006, 290, E916-E924. [CrossRef]

62. van Erp-Baart, A.M.; Saris, W.M.; Binkhorst, R.A.; Vos, J.A.; Elvers, J.W. Nationwide survey on nutritional habits in elite athletes. Part II. Mineral and vitamin intake. Int. J. Sports Med. 1989, 10, S11-S16. [CrossRef] [PubMed]

63. Holmlund-Suila, E.; Enlund-Cerullo, M.; Valkama, S.; Hauta-Alus, H.; Rosendahl, J.; Helve, O.; Hytinantti, T.; Viljakainen, H.; Andersson, S. Sex and Iron Modify Fibroblast Growth Factor 23 Concentration in 1-Year-Old Children. J. Clin. Endocrinol. Metab. 2017, 102, 4526-4533. [CrossRef] [PubMed]

64. Holmlund-Suila, E.; Viljakainen, H.; Ljunggren, Ö.; Hytinantti, T.; Andersson, S.; Mäkitie, O. Fibroblast Growth Factor 23 Concentrations Reflect Sex Differences in Mineral Metabolism and Growth in Early Infancy. Horm. Res. Paediatr. 2016, 85, 232-241. [CrossRef] [PubMed] 
65. Larsson, A.; Carlsson, L.; Gordh, T.; Lind, A.L.; Thulin, M.; Kamali-Moghaddam, M. The effects of age and gender on plasma levels of 63 cytokines. J. Immunol. Methods 2015, 425, 58-61. [CrossRef] [PubMed]

66. Miettinen, M.E.; Smart, M.C.; Kinnunen, L.; Keinänen-Kiukaanniemi, S.; Moilanen, L.; Puolijoki, H.; Saltevo, J.; Oksa, H.; Hitman, G.A.; Tuomilehto, J.; et al. The effect of age and gender on the genetic regulation of serum 25-hydroxyvitamin D-The FIN-D2D Population-Based Study. J. Steroid Biochem. Mol. Biol. 2018, 178, 229-233. [CrossRef] [PubMed]

2018 by the authors. Licensee MDPI, Basel, Switzerland. This article is an open access article distributed under the terms and conditions of the Creative Commons Attribution (CC BY) license (http://creativecommons.org/licenses/by/4.0/). 